\title{
How institutions and gender differences in education shape entrepreneurial activity: a cross-national perspective
}

\author{
Selin Dilli • Gerarda Westerhuis
}

Accepted: 30 November 2017 / Published online: 13 April 2018

(C) The Author(s) 2018

\begin{abstract}
Previous studies offer evidence that human capital obtained through education is a crucial explanation for cross-national differences in entrepreneurial activity. Recently, scholar attention has focused on the importance of education in subjects such as science, technology, engineering, and math (STEM) for the promotion of entrepreneurial activity. To our knowledge, empirical evidence for this link is scarce, despite the emphasis made in the literature and by policy makers on the choice of study at the tertiary level. Given that differences in STEM education are particularly large between men and women, we utilize data from the Global Entrepreneurship Monitor for 19 European countries and the USA. We study the role of these differences in STEM education at the national level for three stages of the entrepreneurial process: entrepreneurial awareness, the choice of sector for entrepreneurial activity, and entrepreneurial growth aspirations. We also test whether the effects of gender differences in education is moderated by the nature of the institutional environment in which entrepreneurs operate. Our findings show that individual-level explanations including education account for the gender differences during all three stages of early-stage entrepreneurial activity. Moreover, countries with greater gender equality in
\end{abstract}

S. Dilli $(\bowtie) \cdot$ G. Westerhuis

Social and Economic History, Utrecht University, Drift 6, 3512 BS Utrecht, Netherlands

e-mail: s.dilli@uu.nl

G. Westerhuis

e-mail: g.k.westerhuis@uu.nl science education are characterized by higher entrepreneurial activity in knowledge-intensive sectors and high-growth aspirations. Thus, next to individual-level education, closing the gender gap in science at the national level can benefit a country as a whole by stimulating innovative entrepreneurial activity.

Keywords Field of education · Entrepreneurship · Gender· Institutions

JEL classifications L26 $\cdot \mathrm{P} 1 \cdot \mathrm{P} 46 \cdot \mathrm{J} 16$

\section{Introduction}

Women constitute $52 \%$ of the total European population but only one third of self-employed workers and business starters in the EU (Eurostat 2007; OECD 2016a, b). Typically, women-owned businesses tend to be smaller, to concentrate on sectors considered to be less profitable by financiers, to involve highly routine tasks, and to have lower growth than male-owned businesses (De Bruin et al. 2006; Minniti 2009; McCracken et al. 2015; OECD 2016a, b). In a globalizing world, people who work largely in sectors involving highly routine tasks are thought to be particularly vulnerable (Marques 2017). Inducing women to engage in more ambitious entrepreneurship can thus be an important governmental tool for improving the entrepreneurial climate across countries and regions and could benefit these areas' competitiveness (Van Der Zwan et al. 2011, p. 628). Female entrepreneurs not only contribute to 
employment creation and economic growth through their increasing participation but also add to the diversity and quality of entrepreneurship in the economic process (Verheul and Thurik 2001; Verheul et al. 2006; European Commission 2013; OECD 2016a).

Given scholars' and policy makers' assertions that women represent a large pool of entrepreneurial potential, the role of gender has received substantial attention in recent entrepreneurship research (see Minniti and Naudé 2010 and Hughes et al. 2012 for a review of the literature). Traditionally, gender differences in entrepreneurial activity have been attributed to differences in human and social capital (Greene 2000), risk tolerance (Jianakoplos and Bernasek 1998), access to finance (McCracken et al. 2015), and family responsibilities (Minniti and Nardone 2007). At the contextual level, scholars have focused on structural factors, such as the size of the agricultural and service sectors (Reynolds et al. 2005; Terjesen), unemployment, national wealth, economic growth, and economic freedom (Verheul et al. 2006; Minniti and Nardone 2007); formal institutional factors, such as a large state sector (Estrin and Mickiewicz 2011) and public childcare (Elam and Terjesen 2010); and informal considerations, such as views on gender roles (Marques 2017). Among these factors, human capital obtained through education (i.e., average years of education and tertiary education) plays a crucial role in explaining the gender differences in entrepreneurial activity (e.g., Bates 1995; Delmar and Davidsson 2000; Brush and Brush 2006).

In our view, general educational attainment can provide only part of the explanation for the gender gap in entrepreneurial activity because greater educational attainment does not always translate into better labor outcomes for women. For instance, Duquet et al. (2010) show that despite their generally higher educational attainment, young women are characterized by lower labor market positions than men in Belgium. Notwithstanding the closing gender gap in higher levels of educational attainment during the second half of the twentieth century, the size of the gender gap in innovative sectors remains large (Marques 2017). Among entrepreneurs in most efficiency-driven economies in Europe and innovation-driven regions, women are more likely than men to have a high level of education; however, women exhibit a total early-stage entrepreneurial activity (TEA) rate less than half that of men (Kelly et al. 2015). This study examines the relevance of two alternative explanations for this gap next to formal general education.

First, the choice of study can be important for understanding the gender gap, especially in innovative entrepreneurial activity. While the number of necessitydriven female entrepreneurs is relatively high globally, there is a greater gender difference among high-growth businesses (Brush et al. 2004). To foster (high-growth) entrepreneurial activity, the European Commission (2013) and a number of scholars (e.g., McCracken et al. 2015) highlight that girls and young women should be encouraged to pursue science, technology, engineering, or mathematics (henceforth, STEM) subjects at schools and universities. In the present study, we focus on the impact of the population's distribution of education in STEM subjects. To our knowledge, there are no individual-level data on entrepreneurs' choice of study field, which would allow us to test our hypothesis at the individual level. Nevertheless, we argue that closing the gender gap in science education at the country level is beneficial for (female) entrepreneurial activity because it stimulates a gender-egalitarian environment by creating role models for female entrepreneurs.

Encouraging women to study STEM subjects is not only relevant for closing the gender gap in entrepreneurial activity but may also have benefits for the overall level of entrepreneurial activity. Because women are largely underrepresented in STEM fields, increasing the share of female students in STEM can help overcome the skills shortage in STEM fields. This has received attention as an important contributor of innovation and venture creation. However, little evidence exists on the relationship between gender differences in STEM education and entrepreneurial activity (BlumeKohout 2014).

Second, the relationship between human capital and an individual's occupational choice is sensitive to the institutional context (Estrin et al. 2016, p. 454). There is a general consensus among scholars that institutions affect entrepreneurial activity. Many studies have examined how institutions can help explain gender differentials in entrepreneurial activity (e.g., Verheul et al. 2006; Minniti and Nardone 2007; Elam and Terjesen 2010; Estrin and Mickiewicz 2011; Marques 2017). For instance, Estévez-Abe (2006) shows that the same institutions affect men and women differently, and finds that vocational training systems and internal labor market systems exacerbate gender inequality. Therefore, one can expect that institutional arrangements in a particular 
country will affect the extent to which human capital stimulates male and female entrepreneurs. For instance, in contexts where attitudes toward gender roles are more traditional and STEM fields are dominated by men, women might be discouraged to make a career choice in STEM.

With these issues in mind, this paper aims to answer two main research questions: (1) to what extent do the (long-term) gender differences in STEM education at the tertiary level play a role in explaining the crossnational (gender) differences in entrepreneurial activity? and (2) to what extent do institutions influence the relationship between human capital and the gender gap in entrepreneurial activity? To address these questions, we use the Global Entrepreneurship Monitor (GEM) database in combination with macro-level data from various online data sources. We use multilevel probit regressions to analyze our data.

Consistent with the report from the European Commission (2013), our findings show that the main features of female entrepreneurship are similar across European countries and the USA. On average, women see fewer opportunities to start a business, are less likely to start a business in highly knowledge-intensive business sectors, and are less likely to have aspirations to grow their businesses. Individual factors such as network, skills, and education explain why women are less likely to be involved in entrepreneurial activity during all three stages of entrepreneurial activity. We show that while closing the gender gap in science education does not have gender-specific effects at the individual level, it stimulates the overall level of early-stage entrepreneurial activity in knowledge-intensive business sectors and highly aspirational entrepreneurial activities. Furthermore, the institutional setting plays an important role in increasing the returns of closing the gender gap in science. The highest returns are expected in the continental and Nordic institutional context, which is characterized by good legal systems, moderate employment protection, high government expenditures in education, and female-friendly policies (Perrons 1995).

One implication of our study is that while the returns slightly differ between different institutional contexts, achieving gender equality in STEM education is an important tool to stimulate entrepreneurial activity and is thus "smart economics," as noted by the World Bank (2011). We also discuss the origins of gender differences in science education and whether they have changed over time to identify the possible challenges and feasibility of pursuing policy tools to close the gender gap in tertiary-level science education.

The paper is organized as follows. Section 2 provides a definition of entrepreneurship, followed by a discussion of the role of human capital in explaining the gender gap in entrepreneurial activity. This section then reviews the literature on how institutions shape the link between (type of) education and (female) entrepreneurship. Section 3 explains the data and measurements used to test the hypotheses outlined in Section 2, while Section 4 discusses the results. In Section 5, we discuss the origins of gender differences in science education over time, and Section 6 states our conclusions.

\section{Literature overview}

\subsection{Definition of entrepreneurship}

Various definitions and forms of entrepreneurship exist (Acs et al. 2014). For example, Schumpeter views entrepreneurs as innovators whose function is to carry out new combinations of means of production. According to Knight's (1982) seminal writings, an entrepreneur is someone who makes decisions under conditions of uncertainty. Estrin et al. (2013, p. 412) argue that entrepreneurship - "new entry" during efforts to create a viable business-results from an individual's occupational choice to work on his or her own account.

In this study, we follow Wennekers and Thurik (1999, p. 29), who describe entrepreneurship as an illdefined and, at best, multidimensional concept that requires decomposition at different levels. They argue that two major stages of entrepreneurship can be identified. The first has to do with "new entry" and the second with "innovativeness" in general. As a result, later research began to make a distinction between different stages of entrepreneurial activity (Reynolds et al. 2005; Baumol and Blinder 2011; Henrekson and Sanandaji 2014). Here, we concentrate on three different stages of entrepreneurial activity. In the first stage, we focus on entrepreneurial awareness, that is, whether an entrepreneur sees an opportunity to start a business. In the second stage, we focus on the sector in which the entrepreneur starts a business, as some sectors are more innovative and "entrepreneurial" than others (Wennekers and Thurik 1999; Marques 2017). In the third stage, we examine entrepreneurs' growth aspirations (Estrin and Mickiewicz 2011). As such, our strategy in defining 
entrepreneurship is similar to Dilli et al. (2018). An important motivation to study the role of education in different stages of entrepreneurial activity is Van Der Zwan et al.'s (2011) argument that cross-country gender differences are largest during the conversion of start-up considerations into start-up activities and in business survival rates.

\subsection{Human capital, gender, and entrepreneurship}

A large body of literature shows that education benefits an entrepreneur's performance in different ways, such as business survival, firm growth, or the firm's return on investment (e.g., Van Der Sluis et al. 2008; Millán et al. 2014). For instance, at the national level, De Clercq et al. (2008) find a positive effect of tertiary education on the GEM's TEA rate. At the individual level, education can enhance managerial ability, which increases the probability of entrepreneurship. However, higher levels of education may also generate better outside options (i.e., more lucrative wage employment under better working conditions) and thus decrease the likelihood of entrepreneurship as the preferred choice (Van Der Sluis et al. 2008, p. 798). Empirical findings confirm this indeterminate effect of education level on advancement in the entrepreneurial process (see Van Der Zwan et al. 2013 for a review of the literature).

Studies that have considered the role of gender in entrepreneurship (e.g., Van Der Zwan et al. 2011; Caliendo et al. 2015; Stefani and Vacca 2015) also show that lower levels of female education are a crucial factor in explaining the gender differences in entrepreneurial activity. However, Fig. 1 shows that this link between education and the gender gap in entrepreneurial activity, captured here in terms of self-employment, is not always straightforward. Since the 1980s, the gender gap in tertiary education has closed substantially and even reversed in some industrialized countries, such as Portugal and Ireland. However, despite this progress toward gender equality, the gender gap in self-employment rates has persisted over time in many European countries, such as Germany and Spain, and even increased in the case of Great Britain and Portugal. This could be because higher levels of female education create better opportunities for women's wage employment and, therefore, lead to lower levels of self-employment (see Verheul et al. 2006 for evidence of this link). However, the increasing levels of female labor force participation in Germany and Spain since the 1980s (ILO 2017) do not seem to be reflected in the trends of gender gap in self-employment of these two countries presented in Fig. 1. Moreover, this link is expected to be strongest in countries where women are largely engaged in necessity-motivated entrepreneurial activity with lowpaid businesses. In summary, because the trends in Fig. 1 vary across countries, the aggregate picture of general education and the overall level of self-employment activity provide limited insight into the link between education and entrepreneurial activity.

We therefore argue, first, that it is important to consider the differing impacts of formal education during various stages of entrepreneurial activity. In their meta-analysis, Van der Sluis et al. (2008) show that education's impact on entrepreneurial activity differs depending on the stage of entrepreneurial activity. While the impact of education on the first stage of the entrepreneurial process, which is selection into entrepreneurship, is insignificant, the effect on performance, as captured by indicators such as the number of employees, is positive and significant (see also Van Der Zwan et al. 2013). Other studies demonstrate that education impacts selection into some sectors as self-employed, particularly in the so-called "knowledge industries," such as the information and communication technology (ICT) industries (Bosma et al. 2002). Similarly, according to Bates (1995), increasing levels of women's education (captured by tertiary education) are the strongest predictor of why women are more likely to enter self-employment in skilled service fields in the USA. Likewise, focusing on GEM data for a single sector (hotels and restaurants), RamosRodriguez et al. (2012) find that women are 50\% more likely to enter this sector as entrepreneurs than men, while education has no impact on their choice.

\section{H1: Entrepreneurs' education levels are not linked with seeing opportunities; they are positively relat- ed to engagement in highly knowledge-intensive sectors and high-growth aspirations.}

Second, it is important to consider whether the impact of education on entrepreneurial activity differs between men and women. The evidence for this link is ambiguous. For instance, Marques (2017) finds that while education is positively associated with higher participation of both women and men in low-routine sectors, the influence of education level is not gendered. Van der Sluis 

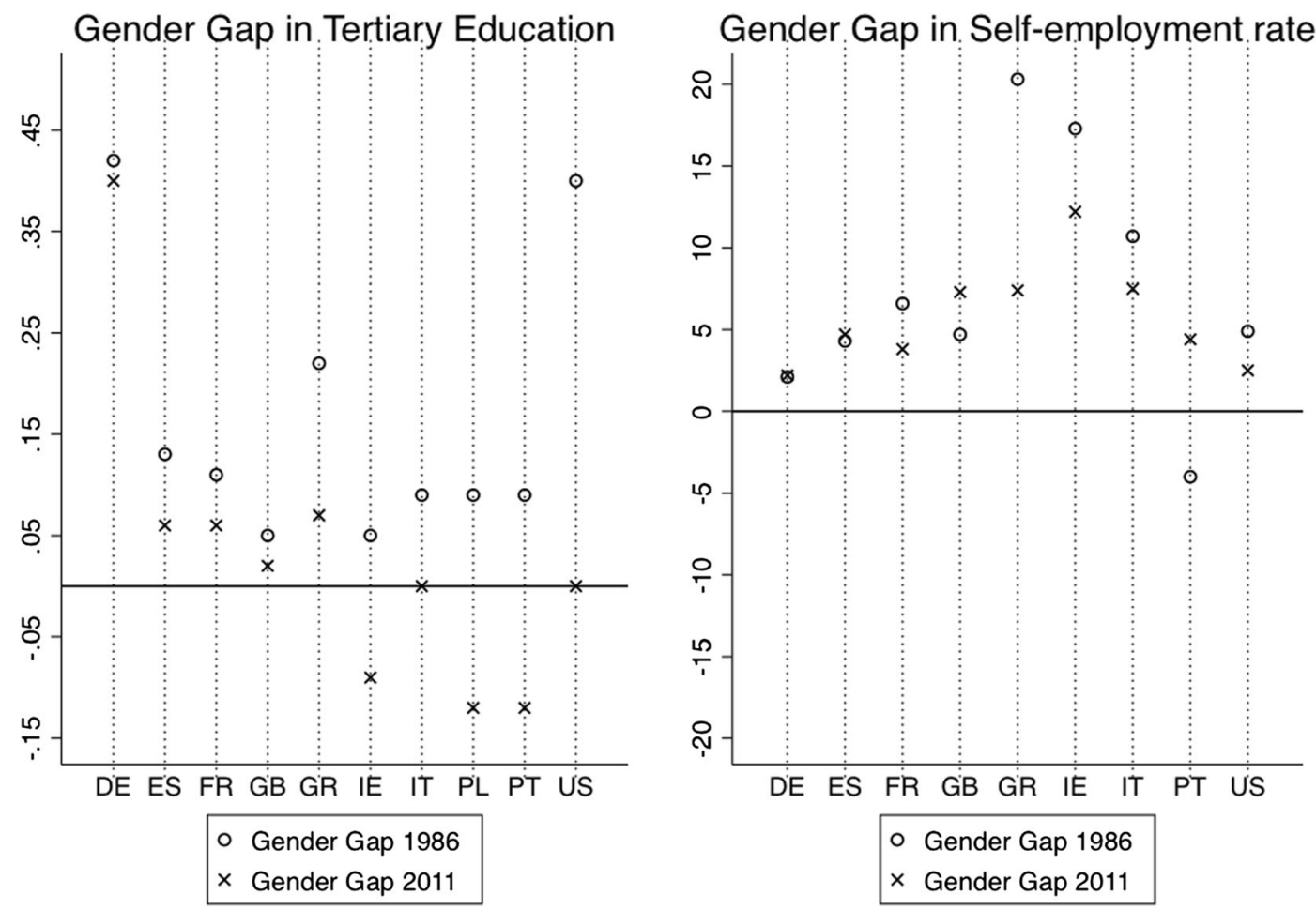

Fig. 1 The gender gap in tertiary education versus self-employment rate. Source: the data on tertiary educational attainment comes from Barro and Lee (2013), and the figure on self-employment is based on OECD statistics

et al. (2008) show that the effect of college graduation on the probability of selection into an entrepreneurial position is higher in the USA than in European countries and is the same for males and females. According to their analysis, though, the link between education and performance seems to be stronger for women than for men. However, these studies focus on the role of education on those that actually start up a business. A higher educational level can lead to lower entrepreneurial activity among women because traditional gender role attitudes and care duties can discourage women from pursuing entrepreneurship as a career choice in the first place. These gender differences can be relevant in understanding why men and women with similar levels of education would be less likely to participate in knowledge-intensive sectors and in growing their businesses. Therefore, we formulate the following hypothesis:

$\mathrm{H} 2$ : The impact of education on entrepreneurial activity is expected to be lower for women than for men during all three stages of entrepreneurial activity.
Third, it is important to consider not only the entrepreneur's education but also the (type of) education of the population in which entrepreneurs start their businesses. Millán et al. (2014, p. 613) measure educational attainment levels in the population through the share of the population having tertiary education and show that educational attainment at the national level is linked with an individual's entrepreneurship success in terms of survival, earnings, and job creation by own-account workers. According to Millán et al. (2014, p. 613), there are many reasons why a higher education level in the population matters for entrepreneurial activity. Highly educated populations may be characterized by (i) a higher-quality workforce, (ii) a more sophisticated and diverse consumer market, and (iii) more productivity and innovation. At the individual level, entrepreneurs may benefit from a highly educated population because it makes it easier to find qualified personnel. Additionally, a more highly educated consumer market positively affects the demand for consumer products in a qualitative sense such that the demand for innovativeness and diversity increases. Entrepreneurs may also benefit from more diverse consumer demand because it will create opportunities to enter and exploit niche markets. 
Recently, policy makers and scholars have increasingly promoted STEM education as a major focus of enterprise and innovation, based on the belief that these disciplines will guide the development of new businesses and economic growth (Jones 2008). STEM subjects are of particular importance in the creation of scientific knowledge, and the entrepreneurship literature highlights the importance of scientific knowledge for the development of entrepreneurial ventures in general. Caprile et al. (2012) show that there is a skills shortage in STEM fields, creating recruitment challenges for employers in engineering, high tech/IT, and science sectors. Given that women are significantly underrepresented among STEM university graduates (OECD 2015), there is great potential to increase the share of female graduates in STEM fields. Thus, increasing the share of women in STEM fields can contribute directly to the creation of scientific knowledge and, as such, to a more innovative and productive environment. A more innovative and productive environment can create opportunities for both men and women to start businesses in more knowledge-intensive sectors. ${ }^{1}$

H3: Closing the gender gap in STEM education increases selection into knowledge-intensive business sectors and stimulates high-growth entrepreneurial activity by both men and women.

To understand the gender differences in the choice of study, it is important to consider the role of informal institutions. Informal institutions, or social norms and practices, play a key role in determining the societal position of women (Dilli et al. 2015). More specifically, Flabbi and Tejada (2012) find that gender differences in fields of study are strongly related to expectations about labor market outcomes. They show that women who graduate in STEM fields are significantly less likely than men to pursue a career in those fields: $71 \%$ of male graduates work as professionals in STEM fields, while only $43 \%$ of female graduates work as professionals in STEM fields (OECD 2015). In comparison, men and women who pursue degrees in the humanities or health sciences make much more similar choices about the

\footnotetext{
${ }^{1}$ While an entrepreneur's own education in STEM subjects can have direct implications for his or her entrepreneurial activity, we cannot test this link empirically as the GEM database does not provide this information.
}

kinds of careers they pursue (OECD 2012). Traditional perceptions of gender roles strongly influence societal ideas of what constitute "masculine" and "feminine" vocations, and these ideas are formed early in life (Kane and Mertz 2011). In the 2012 Programme for International Student Assessment (PISA) test, parents were more likely to expect their sons to work in STEMrelated fields than their daughters - even if their children performed at the same level in mathematics (OECD 2015). Closing the gender gap in STEM education can change attitudes toward feminine and masculine vocations, thereby stimulating female involvement in more (knowledge-intensive/innovative) entrepreneurial activity. Therefore, we propose the following hypothesis:

\section{H4: Cross-national differences in STEM education explain gender differences in selection into highly knowledge-intensive business sectors and high- growth aspirations.}

\subsection{Institutions, education, and entrepreneurship}

While many studies have shown that institutions matter for entrepreneurial activity, ${ }^{2}$ fewer studies have paid attention to how institutions help explain gender differentials in entrepreneurial activity (e.g., Elam and Terjesen 2010; Estrin and Mickiewics 2011; Lewellyn and Muller-Kahle 2016; Marques 2017). In a comparative study of 55 countries, Estrin and Mickiewicz (2011) find that women are less likely to undertake entrepreneurial activity in countries with a larger state sector and show that restrictions on the freedom of movement away from home make it less likely for women to have high aspirations for employment growth, even if their entry into entrepreneurial activities is not affected by these restrictions. Among cultural factors, Baughn et al. (2006) show that when a society has more genderegalitarian values, women show greater involvement in entrepreneurship. In contrast, Lewellyn and Muller-


relevance of government regulations, availability of capital, government quality (e.g., level of corruption), and public policies governing the allocation of rewards to enable, enhance, or foster entrepreneurship at both the individual and the national levels (see Stenholm et al. 2013 and Bruton et al. 2010 for a review of the literature). More recently, research has examined the importance of informal institutions such as individual networks, local initiatives, national culture, individualism, trust, and attitudes toward entrepreneurial activity (Hechavarria and Reynolds 2009; Simón-Moya et al. 2014).
} 
Kahle (2016, p. 770) argue that in societies where women are expected to fulfill traditional family responsibility functions (child-rearing and housekeeping), entrepreneurial activity may provide greater flexibility than working in the established business sector. Moreover, such institutional structures are also important for understanding the link between education and (gendered) entrepreneurial activity (Estrin et al. 2016). According to Estrin et al. (2016, p. 454), the relationship between human capital and an individual's occupational choice is sensitive to the institutional context. They show that when the rule of law is strong, it ensures that commercial entrepreneurs benefit more from their human capital in their ventures; however, they do not observe the same effect for social entrepreneurs.

While studying the role of institutions in entrepreneurial activity, it is important to consider the complementarity between them (Dilli et al. 2018). Research on the varieties of capitalism ( $\mathrm{VoC}$ ) approach shows large differences between national economies (e.g., in terms of their innovativeness and sectoral specialization) due to their institutional arrangements related to the supply of knowledge, interfirm relations, finance, and labor, which support each other (Hall and Soskice 2001). Based on these four dimensions of institutions, Hall and Soskice (2001) identify two main clusters among capitalist industrial nations: liberal market economies (LMEs) and coordinated market economies (CMEs). In LMEs, firms coordinate their activities via competitive market arrangements, while in CMEs, firms depend heavily on non-market relationships, such as cooperation among economic actors. Because LMEs are characterized by flexible labor market institutions, the education system supports investments in general skills (Hall and Soskice 2001). In CMEs, because the labor market is more regulated, educational systems and inhouse training encourage the development of industryspecific skills. Therefore, the return on investment associated with specific human capital (e.g., field of education) is expected to be higher in CMEs than in LMEs (Jackson and Deeg 2006). As formal education and investment in specific human capital are more important in CMEs, having fewer graduates from STEM subjects can matter more for the three stages of entrepreneurial activity in CMEs than in LMEs. We therefore hypothesize the following:

H5: The impact of gender differences in STEM education on entrepreneurship is smaller in LME institutional constellations where investment in general skills is more important.

Within the VoC literature, a number of scholars have called for attention to gender dynamics (Estevez-Abe 2009; Folbre 2009; Mandel and Shalev 2009). For instance, Estévez-Abe (2006, p. 152) shows that in CMEs, strong employment protection exacerbates employers' discrimination against women and promotes their investments in male human capital because firm-specific skills present high risks for women who are likely to interrupt their careers due to family-related contingencies. Moreover, CMEs typically have more generous social welfare policies, including those related to families, such as maternal leave and childcare. When these welfare benefits are linked with job tenure, it can make it less attractive for women to pursue careers as entrepreneurs. However, the flexibility that self-employment provides can be particularly attractive for women in contexts where there is no formal institutional support for childcare.

In LMEs, on the other hand, while women's participation in the labor market is usually high, the quality of participation is low because competition is expected to eliminate systematic discrimination. The liberal market approach means that women who wish to combine employment with motherhood are forced into low-paid, part-time jobs. This implies that women can be overrepresented in necessity-based entrepreneurial activity in LMEs (Perrons 1995). Contrarily, the generous welfare environment of CMEs can be supportive of ambitious and opportunity-driven female entrepreneurs because they would be likely to earn enough (in the long run) to afford social security contributions and benefit from them. Following this reasoning, we formulate the following hypothesis:

\section{H6: The size of the gender gap in all three stages of entrepreneurial activity is larger in LMEs.}

It is important to note that in terms of their policies toward female integration into the workforce, European countries are characterized by a larger variation among the CME than the LME countries (Estevez-Abe 2009, p. 6). For instance, Perrons (1995) shows that wage and participation differentials between women and men in the social democratic model practiced by the Nordic countries are among the lowest in the world due to the provision of low-cost, high-quality child care, and the 


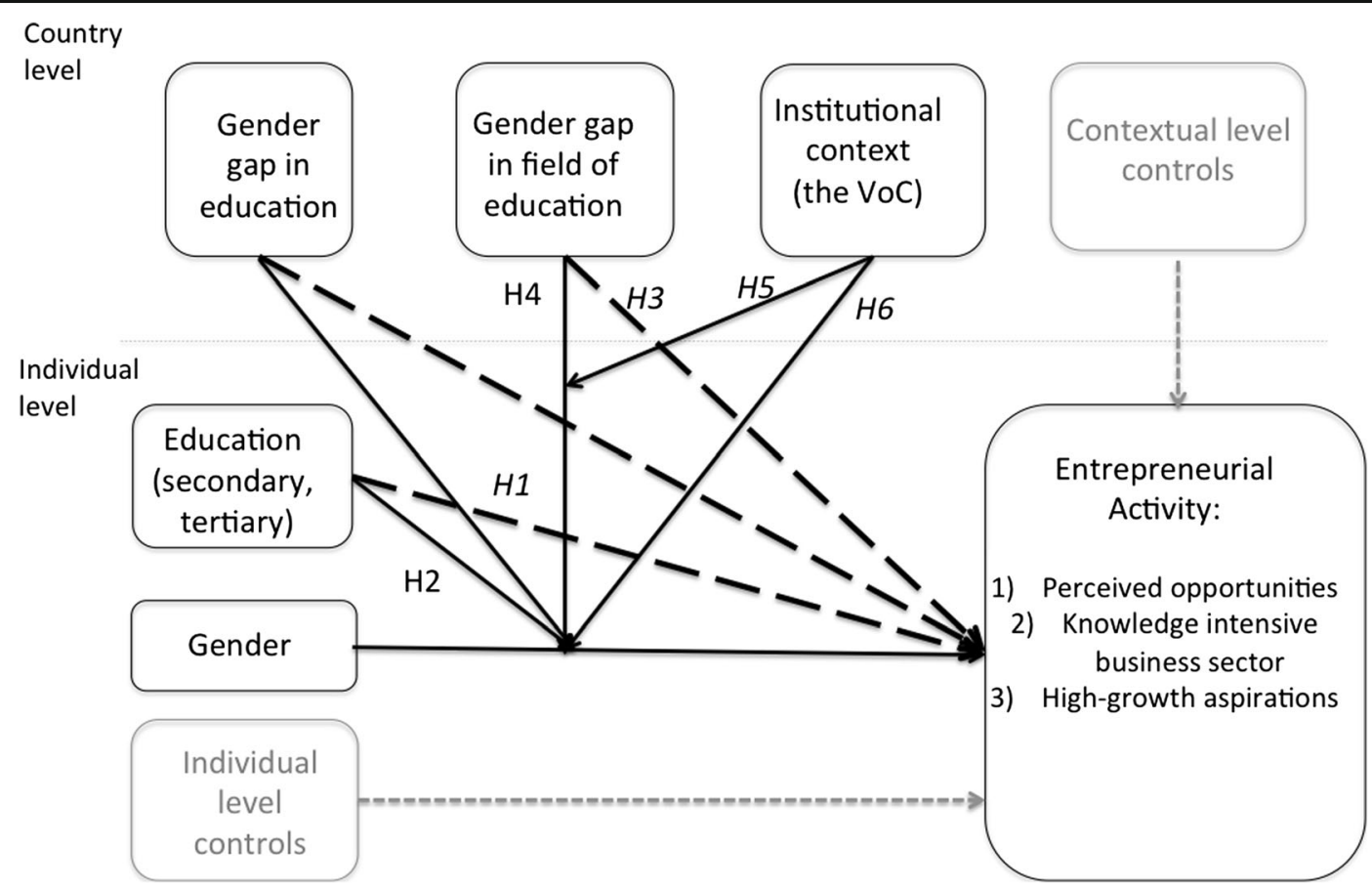

Fig. 2 Theoretical model and hypotheses

system of parental insurance. In Southern European countries, because family often provides the main means of welfare and general financial support, female participation in the labor market is low. As a result, the size of the gender gap in entrepreneurial activity would likely differ among the CMEs depending on the extent to which they follow femalefriendly policies. This means that the size of the gender gap is likely to be smaller in social democratic countries than in the Southern European countries.

Figure 2 summarizes our hypotheses. The solid lines in the figure highlight the gendered effect of education on (individual level) entrepreneurial activity; the dashed lines show the direct effect of gender differences in educational attainment for the overall entrepreneurial activity.

\section{Empirical evidence}

\subsection{Data}

To test our hypotheses, we use the well-known GEM database. The GEM database includes data from a representative national sample of at least
2000 respondents and offers comprehensive data on different forms of entrepreneurial activity, providing us a unique opportunity to answer our research questions. However, one limitation of the GEM data is that it does not provide information on entrepreneurs' choice of study at the university level. To our knowledge, no publicly available individual-level cross-nationally comparable dataset provides this information.

We limit our analysis to 19 European countries and the USA for three reasons. First, we select those countries that have received the most attention in the varieties of capitalism approach. Second, while we focus on the European context, we include the USA because it has received substantial attention in the literature as an example of an entrepreneurial society. Third, data availability plays a role in our selection of countries. Our sample consists of the following 19 countries, with the number of respondents given in parentheses: Austria (91), Belgium (951), the Czech Republic (39), Denmark (1079), Finland (195), France (124), Germany (901), Greece (239), Hungary (217), Ireland (279), Italy (176), the Netherlands (248), Norway (282), Poland (30), Slovenia (244), Spain (1673), Sweden (284), Switzerland (210), the United Kingdom (UK; 1933), and the USA (1051). 


\subsection{Measurements}

\subsubsection{Dependent variable}

We use three indicators to measure entrepreneurship. Our first indicator is perceived opportunities, which is a dummy variable in which 1 denotes a respondent who sees a good opportunity to start a business in the next 6 months; 0 denotes all others.

Our second indicator of entrepreneurship is whether the respondent engages in TEA in knowledge-intensive business sectors (1) or engages in TEA activity in another sector $(0){ }^{3}$ For this, we use information from the GEM database, which provides individual-level TEA activity by a sector based on the four-digit International Standard Industrial Classification of All Economic Activities (ISIC Rev. 4). According to Eurostat, knowledge-intensive business activities include the manufacture of coke, refined petroleum products, and nuclear fuel; the manufacture of chemicals and chemical products; the manufacture of office machinery and computers; the manufacture of radio, television, and communication equipment and apparatus; the manufacture of medical, precision, and optical instruments, watches and clocks; air transport; financial intermediation (except insurance and pension funding); insurance and pension funding (except compulsory social security); activities auxiliary to financial intermediation; computer and related activities; research and development; other business activities; and recreational, cultural, and sporting activities.

Our third entrepreneurship indicator captures highgrowth aspirations in entrepreneurial activity, defined as entrepreneurs' aspirations at the time of entry to create five jobs or more over a period of 5 years (1) and otherwise (0).

\subsubsection{Independent variables}

Individual level The key independent variable of our analysis, gender, is a dichotomous variable with 0 denoting male and 1 denoting female.

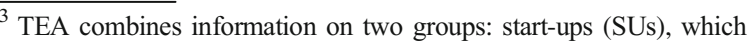
include those involved in setting up a business in the 12 months preceding the survey, and owner-managers (OMs), who began paying wages within a period of less than 3.5 years prior to the survey (Marques 2017, p. 12).
}

We collect a set of socioeconomic and demographic control variables from the GEM database. Education refers to the highest level of education completed by the respondent and is divided into the following four categories: (1) primary (reference category), (2) secondary, (3) post-secondary, and (4) tertiary.

We add control variables for the respondents' personal characteristics including age, skills, and network, which are related to (the gender gap in) entrepreneurial activity (e.g., Verheul et al. 2006; Estrin and Mickiewicz 2011; Van Der Zwan et al. 2011; Marques 2017). Age is a continuous variable that is centered around its group mean. ${ }^{4}$ We add a dummy variable for the entrepreneur's prior knowledge of starting a business, which codes whether the entrepreneur has the knowledge, skills, and experience to start a new business (1) or not (0). This variable captures other skills important to establishing a business that can be learned through formal education as well as other channels, such as work experience. We also add a dummy variable on whether the respondent personally knows someone who has started a business in the past 2 years (1) or not (0) to control for the importance of personal networks in our analysis. ${ }^{5}$ Table 1 provides descriptive statistics for all individuallevel variables broken down by gender.

Contextual level To capture the gender gap at the secondary and tertiary levels, we use the average years of secondary and tertiary schooling among the adult population aged over 25 for men and women by Barro and Lee (2013). We take the ratio of women to men in average years of education at the secondary and tertiary levels. A score less than 1 suggests that girls are more disadvantaged than boys, and a score greater than 1 suggests the opposite. Moreover, we gather data on the distribution of tertiary graduates by a field of study for men and women from the United Nations Educational,

\footnotetext{
${ }^{4}$ We also introduced a quadratic term for age (Estrin and Mickiewicz 2011). However, we do not find a significant effect of the quadratic term for age in two of our models (model opportunity $p_{\text {age } 2}=0.839$, model knowledge-intensive $p_{\text {age } 2}=0.433$ ). There is evidence for a $\mathrm{U}$ shaped link between age and high-growth entrepreneurship, though this link is not very strong $(p=0.06)$. Therefore, we exclude it from our analysis.

${ }^{5}$ In addition to these indicators, we also tested for the effect of fear of failure and necessity as a reason to start a business on the gender gap. However, the results of the $t$-test $\left(p_{\text {failure }}=0.978\right.$ and $\left.p_{\text {necessity }}=0.88\right)$ do not show evidence of a significant difference between men and women in our sample, and we, therefore, excluded these factors from the analysis.
} 
Table 1 Descriptive statistics for all individual-level variables across 19 European countries and the USA

\begin{tabular}{|c|c|c|c|c|c|}
\hline & Range & Men & Women & Sig. test & $N$ \\
\hline \multicolumn{6}{|l|}{ Dependent variables } \\
\hline Perceived opportunity & $0-1$ & 0.58 & 0.54 & $* * *$ & 10,244 \\
\hline TEA in knowledge-intensive business sectors & $0-1$ & 0.20 & 0.14 & $* * *$ & 8390 \\
\hline High-aspiration entrepreneurial activity & $0-1$ & 0.32 & 0.21 & $* * *$ & 9451 \\
\hline \multicolumn{6}{|l|}{ Independent variables } \\
\hline Female & $0-1$ & 0.63 & 0.37 & - & 10,244 \\
\hline Education level (Ref. primary) & & & & & 10,244 \\
\hline Secondary education & $0-1$ & 0.50 & 0.48 & $* *$ & 10,244 \\
\hline Post-secondary education & $0-1$ & 0.29 & 0.28 & n.s. & 10,244 \\
\hline Tertiary education & $0-1$ & 0.18 & 0.20 & $* *$ & 10,244 \\
\hline Know entrepreneur & $0-1$ & 0.66 & 0.56 & $* * *$ & 10,244 \\
\hline Required skills & $0-1$ & 0.88 & 0.78 & $* * *$ & 10,244 \\
\hline $\operatorname{Age}^{\mathrm{a}}$ & $15-97$ & $39.29(12.07)$ & $40.52(11.41)$ & $*$ & 10,244 \\
\hline
\end{tabular}

Source: Global Entrepreneurship Monitor (2002-2009); significance tests for gender differences are conducted through $t$-tests $* * * p<0.01 ; * * p<0.05 ; * p<0.10$ ( $p$ values are two-sided)

${ }^{\text {a }}$ Variables are group mean-centered in our analyses

Scientific and Cultural Organization (UNESCO) statistical yearbooks. We calculate the ratio of female to male graduates in the fields of (1) engineering, manufacturing, and construction; (2) science, which includes life sciences, physical sciences, mathematics and statistics, and computing; and (3) social sciences, business, and law. Data for the three education variables are available for the 1970-2015 period.

To capture diversity in the institutional context, we use the classification provided by Dilli et al. (2018), who provide a typology for the institutional constellations relevant to entrepreneurial activity based on the VoC framework. They show four distinct bundles of institutional constellations relevant to the current study: (1) a liberal market economy (reference category), including the USA, the UK, and Ireland (LMEs); (2) a Nordic/continental European model, including Austria, Belgium, Germany, the Netherlands, Finland, Denmark, Norway, Switzerland, and Sweden (CMEs); (3) a Mediterranean model, including France, Greece, and Spain (MMEs); and (4) an Eastern European model, including Hungary, Czech Republic, Slovenia, Slovakia, and Italy (EMEs).

While Dilli et al.'s (2018) classification focuses on formal institutions, it is also important to consider informal institutions to understand the gender gap in entrepreneurial activity (Verheul et al. 2006). We include a composite indicator provided by the GEM National Expert Survey database on attitudes toward gender roles at the national level. The composite indicator is based on an average of five items measured at the country level: (1) whether men and women have the same level of knowledge and skills to start a business, (2) whether men and women are equally exposed to good opportunities to start a business, (3) whether men are encouraged to become self-employed or start a new business, (4) whether starting a new business is a socially acceptable career option for women, and (5) whether there are sufficient services available for women to start a business. A higher score on the index indicates more gender-egalitarian attitudes. We also control for the level of economic development, captured by the log of GDP per capita, which is available from the World Bank (2016). ${ }^{6}$ Table 2 provides descriptive statistics of the contextual country-level variables.

\footnotetext{
${ }^{6}$ As is common in cross-national research, various observations were missing from some of our contextual indicators. We dealt with missing observations at the contextual level before conducting the regression analysis using intrapolation.
} 
Table 2 Summary statistics for contextual-level variables in 19 European countries and the USA

\begin{tabular}{|c|c|c|c|c|c|c|c|c|c|}
\hline Country & Year $^{\mathrm{a}}$ & $\begin{array}{l}\text { Gender } \\
\text { Eq. Sec. }\end{array}$ & $\begin{array}{l}\text { Gender } \\
\text { Eq. Ter. }\end{array}$ & $\begin{array}{l}\text { Gender Eq, } \\
\text { EMC }^{\mathrm{c}}\end{array}$ & $\begin{array}{l}\text { Gender Eq. } \\
\text { science }^{c}\end{array}$ & $\begin{array}{l}\text { Gender Eq. } \\
\text { sociall }^{\mathrm{c}}\end{array}$ & VOC $^{d}$ & $\begin{array}{l}\mathrm{Ln} \\
\mathrm{GDP}^{\mathrm{c}}\end{array}$ & $\begin{array}{l}\text { Gender } \\
\text { attitude }^{\mathrm{e}}\end{array}$ \\
\hline Austria & 2005, 2007-2009 & 0.95 & 1.191 & 0.21 & 0.99 & 1.26 & CME & 10.74 & 2.99 \\
\hline Belgium & 2002-2009 & 1.02 & 1.22 & 0.21 & 0.68 & 0.96 & CME & 10.67 & 3.22 \\
\hline Denmark & $2002-2009$ & 1.02 & 1.44 & 0.41 & 0.64 & 0.78 & CME & 10.96 & 3.57 \\
\hline Finland & 2002-2009 & 1.06 & 1.22 & 0.18 & 0.81 & 1.378 & CME & 10.74 & 4.00 \\
\hline Germany & $\begin{array}{l}\text { 2002-2009 (except } \\
\text { 2007) }\end{array}$ & 0.98 & 0.9 & 0.2 & 0.74 & 0.8 & CME & 10.57 & 2.84 \\
\hline Netherlands & 2001 & 0.98 & 1.09 & 0.16 & 0.51 & 0.82 & CME & 10.79 & 3.13 \\
\hline Norway & $2002-2009$ & 1.01 & 1.55 & 0.21 & 0.65 & 0.75 & CME & 11.37 & 3.87 \\
\hline Sweden & 2002-2007 & 1.05 & 1.54 & 0.26 & 0.75 & 0.97 & CME & 10.8 & 3.47 \\
\hline Switzerland & $\begin{array}{l}2002-2009 \text { (except } \\
2004,2006,2008)\end{array}$ & 0.94 & 0.86 & 0.18 & 0.71 & 0.92 & CME & 11.15 & 2.72 \\
\hline Czech Republic & 2006 & 1.02 & 1.22 & 0.25 & 0.97 & 1.35 & EME & 9.86 & 3.17 \\
\hline Hungary & $\begin{array}{l}\text { 2002-2009 (except } \\
\text { 2007) }\end{array}$ & 0.99 & 1.39 & 0.23 & 0.55 & 1.2 & EME & 9.45 & 2.53 \\
\hline Italy & 2001 & 0.98 & 1.38 & 0.31 & 1.06 & 0.93 & EME & 10.52 & 2.94 \\
\hline Poland & 2004 & 1.01 & 1.4 & 0.06 & 0.49 & 1.11 & EME & 9.17 & 3.12 \\
\hline Slovenia & 2002-2009 & 0.99 & 1.44 & 0.18 & 0.9 & 1.34 & EME & 10.02 & 3.39 \\
\hline Ireland & 2002-2009 & 1.09 & 1.27 & 0.17 & 0.96 & 1.12 & LME & 10.83 & 3.24 \\
\hline UK & 2002-2009 & 1.02 & 1.36 & 0.19 & 0.68 & 0.91 & LME & 10.58 & 3.2 \\
\hline USA & $2002-2009$ & 1.01 & 1.39 & 0.19 & 0.82 & 0.921 & LME & 10.76 & 3.82 \\
\hline France & 2002-2007 & 1 & 1.26 & 0.24 & 0.72 & 1.39 & MME & 10.59 & 3.02 \\
\hline Greece & 2003-2009 & 0.95 & 1.1 & 0.43 & 0.63 & 1.19 & MME & 10.26 & 2.98 \\
\hline Spain & 2002-2009 & 1.06 & 1.24 & 0.28 & 1.06 & 1.26 & MME & 10.36 & 3.23 \\
\hline
\end{tabular}

${ }^{a}$ Years in which the data are available from the Global Entrepreneurship Monitor (GEM). The indicators at the country level have been collected for the corresponding years. The presented values are the mean of the country-level variables for the years indicated

${ }^{\mathrm{b}}$ Source: World Bank (2016)

${ }^{\mathrm{c}}$ Source: UNESCO (2015)

${ }^{\mathrm{d}}$ Source: Dilli et al. (2018)

${ }^{\mathrm{e}}$ Source: GEM National Expert Survey (NES)

\subsection{Analysis}

To model gender differences during the three stages of the entrepreneurial process across 19 European countries and the USA, we use multilevel probit regression techniques, which are suitable due to the binary nature of the dependent variable (Long 1996). Since the GEM data used in our analyses are taken from 20 different countries and represent surveys taken during various years between 2002 and 2009, our data have a hierarchical structure, with individuals nested in countries and years. We can account for this hierarchal structure with a multilevel model (Hox 2010). While multilevel techniques also allow us to model a random slope for gender, we do not add a random slope for "female" because the likelihood ratio tests show that adding a random slope does not significantly improve the estimation models [LR chi-square (1) perceived opportunity $=0.46, p=$ 0.49; LR chi-square (1) knowledge-intensive sector $=$ $0.00, p=0.99$; LR chi-square (1) high aspiration $=2.74$, $p=0.10]$. This finding already supports the European Commission's view $(2013$, p. 8) that the main features of female entrepreneurship are similar across these countries.

To test our hypotheses, we follow a similar strategy as Estrin and Mickiewicz (2011, p. 404) and introduce random country-year effects to all our estimates, which accounts for unobserved heterogeneity across countries and for measurement errors and idiosyncrasies that are country-year sample specific. While the introduction of 
three levels with countries and years as separate levels is an alternative, the unbalanced structure of the GEM database creates estimation problems. Moreover, even when we retest our (base) models with three levels instead of two, the interpretation of the results presented below does not change. Additionally, estimates with country-fixed effects are not possible due to the slowly varying nature of our institutional indicators (e.g., Alesina et al. 2011).

In sum, we estimate the following equation:

$$
\begin{aligned}
& \operatorname{Prob}(\text { Enprepreneurial activity })_{i j t}= \\
& f\left(\text { Female }_{i j t} \text {, Education }{ }_{i j t}\right. \text {, Individual- } \\
& \text { Level controls }{ }_{i j t} \text {, Gender gap in secondary and tertiary education } \\
& \text { Gender gap in the field of education } j t, \text { Institutional complementarities }\left(\mathrm{VoC}_{j t}\right. \text {, } \\
& \text { Gender attitudes } j t, \ln (\mathrm{GDPpc})_{j t} \text {, Interaction effects between } \\
& \text { individual characteristics } s_{i j t} \text {, Gender gap in education }{ }_{j t} \text {, Institutions } \mathrm{s}_{j t}, \text {, } \text { male }_{i j t} \text { ) }
\end{aligned}
$$

where $i$ denotes individuals, $j$ denotes countries, and $t$ denotes time. Entrepreneurial activity is a dummy variable denoting whether an individual sees an opportunity to start a business, whether she/he starts a business in knowledge-intensive business sector, and whether he/she is engaged in high-growth startup activity. First, we estimate the relevance of individual predictors and then add the contextual indicators. To test our hypotheses, we also add the interaction effects of an individual entrepreneur being female and of education and institutional variables. All models include year-fixed effects to control for common shocks. We examine for multicollinearity issues by using variance inflation factor (VIF) tests. While the inclusion of all direct effects does not indicate problematic collinearity, we present the interaction models for each contextual variable separately to avoid biased estimates due to multicollinearity issues (Maas and Hox 2005). Moreover, for simplicity, we present only the interaction effects for contextual variables that are significant. For ease of comparison, all continuous variables (on both the individual and contextual levels) in the regression analyses are mean-centered. We present the results of the estimation model in Table 4 in the following section.

Although care must be taken when discussing causality, two points can partially address this issue. The first is the exogeneity of country-level variables relative to the individual. The second is the use of early-stage entrepreneurship data. Country-level variables of interest represent slow-moving cultural conditions that were already in place when individual entrepreneurs first thought about setting up a business (Marques 2017, p. 14). The same reasoning applies to the variable for an entrepreneur's education, which he/she (very often) has received before establishing a business.

\section{Results}

\subsection{Descriptive results}

Table 3 presents mean levels of three stages of the entrepreneurial process broken down by gender for all countries separately. Two important findings are apparent from Table 3. First, women are underrepresented compared to men on average during all three stages of entrepreneurial activity, but the size of the gender gap grows in the later stages in many countries. Additionally, we find no considerable or only small gender differences in the perceived opportunity to start a business in many countries (Austria, France, the Netherlands, Finland, Norway, Sweden, the USA, the UK, Slovenia, and Italy). The gap becomes significant and larger in the later stages of starting a business in these countries. In Spain and Greece, there are no significant gender differences in selection into knowledge-intensive business sectors. In Poland and Ireland, the gender differences are present only in perceived opportunities to start a business but disappear in later stages of the entrepreneurial process.

Second, Table 3 shows the importance of considering the country-level differences in entrepreneurial activity. The level of entrepreneurial activity in all three stages differs substantially across countries. For instance, in countries such as the USA, the UK, and the CME countries, individuals, on average, see more opportunities to start a business and are more likely to start a business in highly knowledge-intensive business sectors. Below, we explore these cross-national differences in entrepreneurial activity in greater detail and test the extent to which they relate to individual characteristics and a country's level of gender equality at the tertiary level, the choice of study at the tertiary level, and the complementarity between institutional structure and attitudes toward gender equality in business. 
Table 3 Mean gender difference in entrepreneurial activity

\begin{tabular}{|c|c|c|c|c|c|c|c|c|c|c|}
\hline \multirow[t]{2}{*}{ Country } & \multicolumn{3}{|c|}{ Perceived opportunity } & \multicolumn{3}{|c|}{ TEA in high knowledge sectors } & \multicolumn{3}{|c|}{ High aspiration } & \multirow[t]{2}{*}{$\mathrm{VoC}$} \\
\hline & Men & Women & Diff. & Men & Women & Diff. & Men & Women & Diff. & \\
\hline Austria & 0.57 & 0.62 & -0.05 (n.s.) & 0.21 & 0.33 & -0.11 (n.s.) & 0.20 & 0.25 & -0.05 (n.s.) & $\mathrm{CME}$ \\
\hline Belgium & 0.60 & 0.54 & $0.05 *$ & 0.13 & 0.06 & $0.07 * * *$ & 0.41 & 0.28 & $0.13 * * *$ & $\mathrm{CME}$ \\
\hline Denmark & 0.49 & 0.41 & $0.08 * * *$ & 0.09 & 0.03 & $0.06^{* * *}$ & 0.40 & 0.29 & $0.11 * *$ & $\mathrm{CME}$ \\
\hline Finland & 0.63 & 0.6 & 0.03 (n.s.) & 0.18 & 0.23 & 0.05 (n.s.) & 0.25 & 0.10 & $0.15 * * *$ & CME \\
\hline Germany & 0.46 & 0.43 & 0.03 (n.s.) & 0.30 & 0.24 & $0.14 * * *$ & 0.32 & 0.18 & $0.14 * * *$ & CME \\
\hline Netherlands & 0.57 & 0.59 & -0.02 (n.s.) & 0.32 & 0.2 & $0.12 * *$ & 0.28 & 0.18 & $0.10 * *$ & CME \\
\hline Norway & 0.68 & 0.72 & -0.04 (n.s.) & 0.25 & 0.11 & $0.14 * * *$ & 0.30 & 0.13 & $0.17 * * *$ & CME \\
\hline Sweden & 0.67 & 0.7 & -0.03 (n.s.) & 0.28 & 0.18 & $0.10^{* *}$ & 0.33 & 0.18 & $0.15^{* * *}$ & CME \\
\hline Switzerland & 0.64 & 0.51 & $0.12 * *$ & 0.29 & 0.15 & $0.13 * *$ & 0.34 & 0.12 & $0.22 * * *$ & CME \\
\hline Czech Republic & 0.55 & 0.37 & 0.18 (n.s.) & 0.10 & 0.4 & $-0.30 * * *$ & 0.45 & 0.47 & -0.02 (n.s.) & EME \\
\hline Hungary & 0.42 & 0.38 & 0.04 (n.s.) & 0.12 & 0.12 & 0.00 (n.s.) & 0.27 & 0.14 & $0.13 * * *$ & EME \\
\hline Italy & 0.49 & 0.48 & 0.01 (n.s.) & 0.18 & 0.16 & 0.02 (n.s.) & 0.35 & 0.28 & 0.07 (n.s.) & EME \\
\hline Poland & 0.54 & 0.12 & $0.42 * *$ & 0.1 & 0.24 & -0.15 (n.s.) & 0.31 & 0.13 & 0.19 (n.s.) & EME \\
\hline Slovenia & 0.53 & 0.62 & $-0.09 *$ & 0.25 & 0.15 & $0.10 * *$ & 0.37 & 0.17 & $0.14 *$ & EME \\
\hline Ireland & 0.54 & 0.63 & $-0.08^{*}$ & 0.30 & 0.27 & 0.03 (n.s.) & 0.25 & 0.21 & 0.02 (n.s.) & LME \\
\hline UK & 0.69 & 0.66 & 0.03 (n.s.) & 0.14 & 0.12 & 0.02 (n.s.) & 0.37 & 0.23 & $0.14 * * *$ & LME \\
\hline USA & 0.70 & 0.65 & $0.05^{*}$ & 0.22 & 0.17 & $0.05^{* *}$ & 0.38 & 0.23 & $0.15 * * *$ & LME \\
\hline France & 0.48 & 0.47 & 0.01 (n.s.) & 0.07 & 0.08 & 0.01 (n.s.) & 0.21 & 0.18 & 0.03 (n.s.) & MME \\
\hline Greece & 0.36 & 0.51 & $-0.15^{* *}$ & 0.06 & 0.06 & 0.00 (n.s.) & 0.16 & 0.02 & $0.14 * * *$ & MME \\
\hline Spain & 0.53 & 0.45 & $0.09^{* * *}$ & 0.20 & 0.17 & 0.03 (n.s.) & 0.23 & 0.20 & $0.03 *$ & MME \\
\hline
\end{tabular}

Source: GEM (2002-2009); significance tests for gender differences are conducted through $t$-tests

n.s. not significant

$* * * p<0.01 ; * * p<0.05 ; * p<0.10$ ( $p$ values are two-sided $)$

\subsection{Multivariate analysis}

The results of our multilevel probit regressions are presented in Table 4. Models 1, 4, and 8 in Table 4, which include only gender as a predictor, show that on average, women are significantly less likely to see opportunities, to be involved in highly knowledge-intensive sectors, and to engage in high-aspiration start-up activity than men, supporting the findings of previous research (e.g., Verheul et al. 2006; Estrin and Mickiewicz 2011; Marques 2017). To obtain a better understanding of the coefficients, we calculate the marginal effects. Accordingly, compared to men, the probability that women will see an opportunity to start a business is on average $3 \%$ smaller, the probability that they will engage in knowledgeintensive sectors is $6 \%$ smaller, and the probability that they will have growth aspirations is $11 \%$ smaller.

Model 2 adds individual characteristics and their interactions with the "female" variable. After including individual-level covariates, the mean gender effect is not significant. This shows that in our sample of countries, gender differences are fully explained by differences in entrepreneurs' individual characteristics. These findings are consistent with the results of previous studies. For instance, Langowitz and Minniti (2007) show that men and women tend to react to the same set of incentives and that much of the difference across genders disappears after correcting for individual differences in socioeconomic conditions. Similarly, a report from the European Commission (2013) identifies individual characteristics such as women's care responsibilities and lack of role models, business networks, and representation as the main barriers to female entrepreneurship.

In particular, tertiary education is associated with higher perceived opportunities and higher chances of selection into knowledge-intensive sectors, whereas it has no impact on high-growth aspirations. This provides only partial support for hypothesis 1 , which states that entrepreneurs' education level is not linked with seeing opportunities; it is positively related with the 


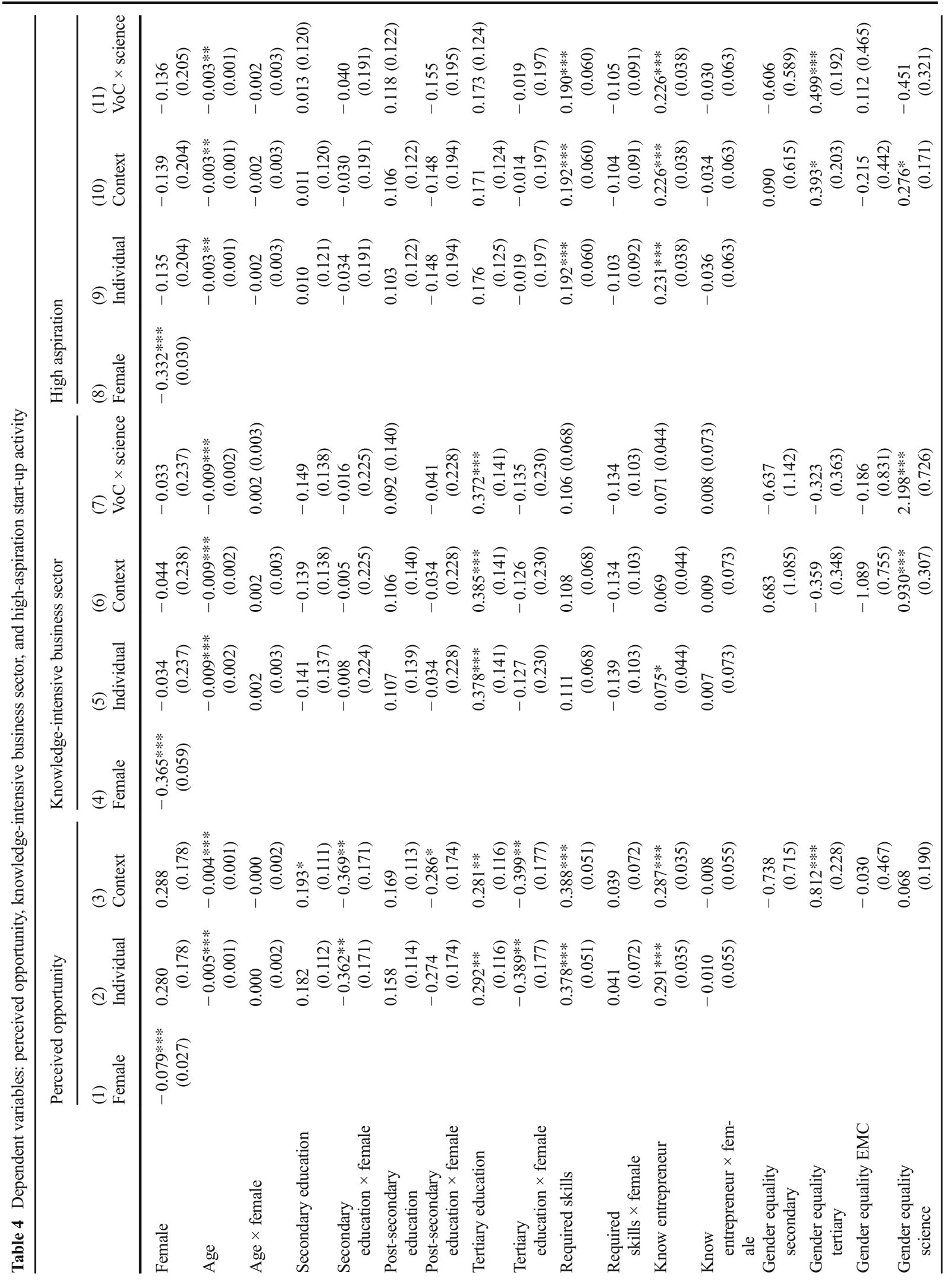







engagement in highly knowledge-intensive sectors and high-growth aspirations. Earlier findings show that education is not linked with whether one starts a business or not (see Van Der Zwan et al. 2013 for a review). The fact that tertiary education does seem to increase the probability of perceiving opportunities to start a business implies that other factors, such as financing or the ease of starting a business, may play a more important role than education in setting up a business. This supports the findings of Van der Sluis et al. (2008), who argue that education has a varying impact during the different stages of entrepreneurship. An explanation for the difference between our findings and those from the previous literature on high-growth aspirations (Van Der Sluis et al. 2008; Estrin and Mickiewicz 2011) may arise from our measurement of entrepreneurial performance. While Van Der Sluis et al. (2008) focus on the entrepreneur's income as a measure of performance, Estrin and Mickiewicz (2011) define a highly aspirational entrepreneur as someone who aspires for firm growth of more than ten employees. We measure entrepreneurial performance as aspirations for the firm growth of more than five employees. Thus, education begins to matter for entrepreneurial performance above a certain threshold. Notably, the influence of educational level is not gendered. Therefore, we do not find evidence to support H2, which states that the impact of education on entrepreneurial activity is expected to be lower for women than for men during all three stages of entrepreneurial activity due to the social arrangements that discriminate against women. ${ }^{7}$ This finding does, however, support the conclusions of Marques (2017) and Van Der Sluis et al. (2008).

Individuals with the relevant knowledge, skills, and experience to start a new business may also see more opportunities to start a business and are more likely to engage in highly knowledge-intensive sectors and to become involved in highly aspirational entrepreneurial activity. This finding is consistent with earlier studies, which show that in their capacity as "jacks-of-all-trades," entrepreneurs may require a broad range of skills (Silva 2007). Being acquainted with an entrepreneur also increases the probability of entrepreneurial activity during all stages of the entrepreneurial process. Both skills and network are factors in which the size of the gender gap is the largest

\footnotetext{
${ }^{7}$ While the interaction term between tertiary education and the "female" variable on perceived opportunity is significant in Table 2, we look at the marginal effects and do not find any evidence (Wald chisquare $\left.(1)=0.53, p_{2 \mathrm{~s}}=0.46\right)$ that the effect of education differs significantly between men and women.
}

among the individual factors (Table 1). Therefore, these areas should be prioritized to close the gender gap in entrepreneurial activity. Consistent with the earlier findings, the probability of seeing opportunities to start a business and of becoming an entrepreneur in knowledgeintensive sectors as well as the possibilities for firm growth are lower for older people. This could be linked to generational constraints and family responsibilities and is especially true for women who are involved in highly knowledge-intensive sectors.

Because individual differences account for the gender gap in entrepreneurial activity, we do not find any support for hypotheses 4 and 6 , which argue that cross-national differences in gender equality with regard to education and institutional environment should help to explain the gender differences in entrepreneurial activity. However, we test the role of gender differences at the contextual level in explaining the cross-national differences in overall levels of entrepreneurial activity, as argued in hypotheses 3 and 5 . The results of models 3 and 10 in Table 4 show that countries with higher gender equality at the tertiary level also have more individuals who see an opportunity to start and grow their business. While the education field does not matter in determining whether an individual sees an opportunity to start a business, in countries with higher gender equality in science, individuals are more likely to engage in knowledge-intensive business sectors and to see opportunities to grow their businesses (models 6 and 9 in Table 4). On average, in countries that achieve gender equality in science education, the probability of finding entrepreneurs in highly knowledge-intensive sectors is $25 \%$ higher, and the probability of finding entrepreneurs with high-growth aspirations is $10 \%$ higher relative to countries that do not. This finding provides support for hypothesis 3. Consistent with the conclusions of Dilli et al. (2018), individuals see significantly fewer opportunities to start a business in the Mediterranean and Eastern European market economies than in the liberal market economies. Individuals also have lower growth aspirations in the Mediterranean economies than in the liberal market economies. Interestingly, more individuals are engaged in knowledgeintensive sectors in coordinated/Nordic market economies than in liberal market economies.

Models 7 and 11 in Table 4 test whether the impact of gender equality in science on entrepreneurial activity varies across different institutional constellations. Figure 3 


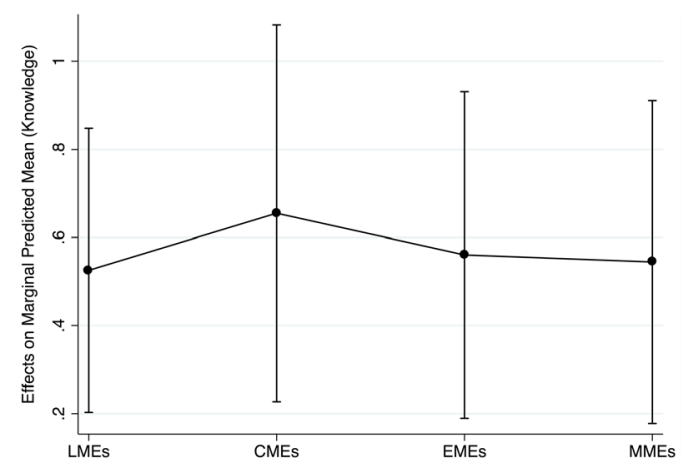

Fig. 3 Marginal effects of gender equality in science

presents the marginal effect of the gender gap in science calculated over four institutional constellations based on models 7 and 11 in Table 4, including both the main and the interaction terms. According to Fig. 3, the benefits of closing the gender gap in science for entrepreneurial activity in knowledge-intensive businesses are highest in the CMEs. This could be due to the fact that the CMEs have moderate employment protection and higher governmental expenditure in education than other institutional contexts, which can stimulate investment in highly specific skills. Moreover, CMEs generally pursue more female-friendly policies, which means that women who pursue education in science subjects are more likely to pursue a career in the same field. This provides partial evidence for our hypothesis 5, which argues that the impact of gender differences in STEM education on entrepreneurship is smaller in LME institutional constellations where investment in general skills is more important. However, we do not find any evidence that the impact of gender equality in science education on perceived opportunities or highgrowth aspirations varies substantially among different institutional constellations.

\section{Gender equality in education and entrepreneurship over time}

Based on our analysis of recent data above, we extract two main findings: (i) gender differences in entrepreneurial activity are explained by differences in individual characteristics - for example, female entrepreneurs are less involved in entrepreneurial networks and have less prior start-up experience - and (ii) closing the gender gap in science education will increase a country's

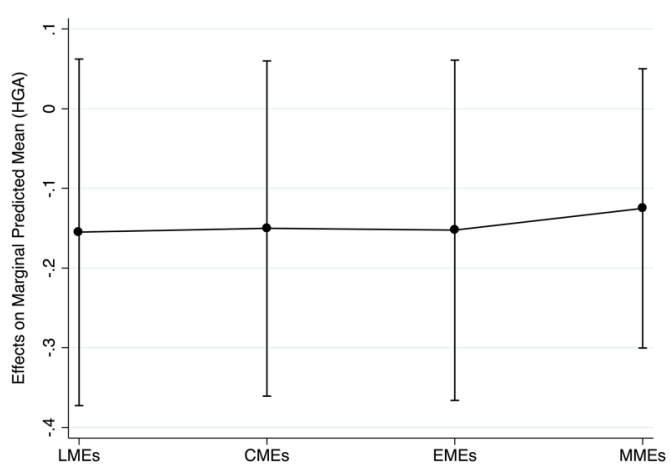

general level of entrepreneurial activity in knowledgeintensive sectors and its growth aspirations. We now discuss the origins of gender differences in science and whether these differences have changed over time to identify possible challenges and the feasibility of pursuing policy tools for closing the gender gap in tertiarylevel science education.

Figure 1 shows that gender gaps in self-employment persisted and even increased between 1986 and 2011 in some countries. At the same time, tertiary education expanded enormously in all EU member states, and women have attained equality with men in terms of educational attainment (Reimer and Steinmetz 2009, Fig. 1). However, as argued above, despite initiatives to promote gender equality in science education, the gap between women and men in this field has only slightly lessened since 2000, and women continue to be largely underrepresented (OECD 2012).

Figure 4a shows that there has been a clear increase in science education in all four $\mathrm{VoC}$ types since the 1990s, with LME countries having the highest level followed by mixed market economies (MMEs), CMEs, and European market economies (EMEs). However, the increase in the share of the population receiving science education has not translated into higher gender equality. Instead, all VoC categories show a rather steep decrease in the share of women in science fields compared to men since the mid-1990s. The only exception occurred during the 1970s, when women in LMEs received more science education at the tertiary level. Interestingly, while the size of the gender gap biased against women was largest in CMEs, followed by LMEs and MMEs, and EMEs before the 1990s, a convergence toward gender inequality in science education has occurred. A sharp decline was visible, particularly in EMEs after the collapse of the Soviet Union. An explanation for this 
a Share of Population in Science Subjects

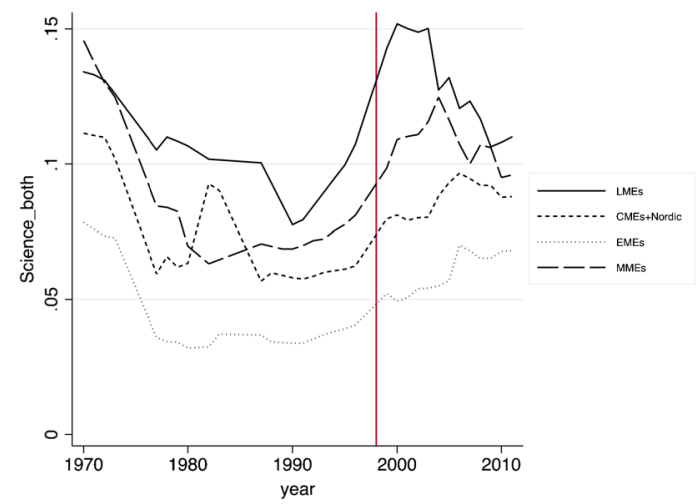

b Gender Gap in Science Subjects

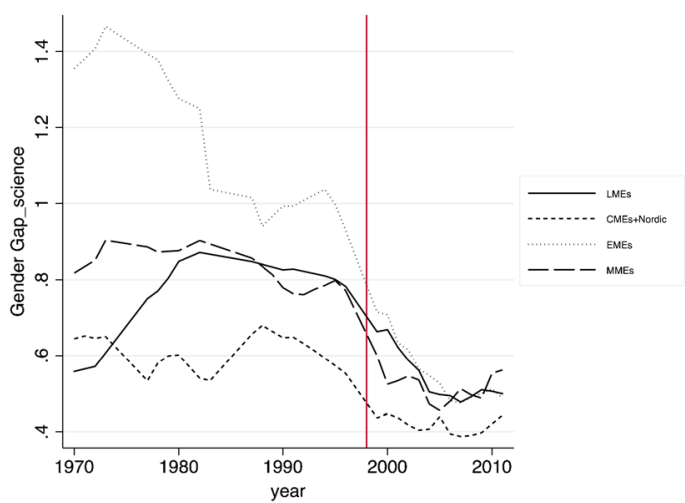

Fig. 4 a Share of the population in science education, b Presents the gender differences in science education. Gender gap and overall study choice in science education over time

increasing gap can be due partially to changes in women's choices to pursue careers in other fields, such as health. ${ }^{8}$

Why do women choose science education less frequently than men? This question is often explained by analyzing how individual and social factors shape gendered motivation and young girls' and boys' career plans. It is argued that the gender gap in science achievement widens with every step in an individual's educational and professional life, from high school to college to graduate school, and into the ranks of academia or industry (Leaper 2014; Schoon 2014). For example, Eccles (2014) describes families' influences on gender differences in science discipline and how parents' beliefs differ according to the sex of their child. These more informal institutions related to gender role attitudes are highly embedded and usually result from historical processes, which makes them difficult to change. The worsening gender equality ratios in science education over time (Fig. 4b) also indicate that long-term institutional explanationsnot only economic development-are important for explaining gender differences (Dilli et al. 2015). This should be kept in mind when designing policies aimed at achieving gender equality in science education.

\footnotetext{
${ }^{8}$ When interpreting these trends, a word of caution is necessary. UNESCO stopped presenting its data in a statistical yearbook in 1998 and shifted to publishing it online (highlighted with a red reference line in the figures), which could explain some of the decline in the figures.
}

\section{Conclusion}

The flow of knowledge to entrepreneurs via education is relevant for creating a European entrepreneurial ecosystem. This article investigates the (gendered) role of individual-level and country-level educational factors during different stages of entrepreneurial activity in 19 European countries and the USA from 2002 to 2010. In particular, we study the role of the gender differences in STEM education at the country level in promoting women's and men's perceived opportunities to start a business, the knowledge intensiveness of the sector in which they start their business, and their growth aspirations. Gender roles, we show, are highly embedded in informal institutions and persist over time. This implies that when aiming to create an entrepreneurial society in Europe, it is important to consider gender-specific policy tools.

Our findings show that women are generally less likely to engage in all three stages of entrepreneurial activity. This seems to be a general phenomenon in all European counties and the USA because the size of the gender gap does not vary much across countries. Individual differences in prior knowledge on starting a business and an individual's network explain these gender differences. Furthermore, we show that while gender differences in STEM education do not directly impact female entrepreneurial activity, the gender gap in science education is negatively correlated with entrepreneurial activity in knowledge-intensive sectors and high-growth aspirations. The benefits of closing the gender gap in science education on involvement in knowledge-intensive business sectors are likely to be greatest in Nordic/continental Europe. Because of these nations' good legal systems, 
moderate employment protections, high governmental expenditures in education, and more female-friendly policies in general, complementarity with the overall institutional framework will enhance these returns.

From a policy perspective, a number of implications emerge from the current study. First, when closing the gender gap in entrepreneurial activity, it is important to target eliminating gender differences in individual resources, particularly in skills related to entrepreneurial activity learned through channels other than education, such as internships, and to create opportunities for women to network with other entrepreneurs. Women remain disadvantaged in these two areas. Second, our findings show that closing the gender gap - especially in science education-can help increase engagement in knowledge-intensive sectors and high-growth entrepreneurial activity. Third, closing the gender gap in science education is beneficial because it can stimulate entrepreneurial engagement in highly knowledge-intensive sectors, particularly in institutional contexts that support female-friendly policies and have a high-quality institutional environment with moderate levels of employment protection and high investment in education. Fourth, the size of the gender gap in science seems to have increased rather than decreased over time. Gender roles are deeply embedded in cultural institutions. Policies that aim to close the gender gap in science at the tertiary level should target gender differences that emerge during the early stages of an individual's life, particularly at the family level (OECD 2012; Dilli et al. 2015).

An interesting direction for future research is to consider the flows of highly skilled migrants with a science background as closing the gender gap in science education can be less urgent for countries that receive highly skilled migrants. Thus, while the demand for employees with science education is increasing (OECD 2012), the challenges for entrepreneurial activity that arise from gender inequality in science education are likely to differ between countries depending on whether they tend to receive or send migrants. This could also be an important dimension to consider in policy making. More research, however, is needed to verify this claim.

Another direction for future research is related to data collection. A limitation of our research is the lack of individual-level data, which would provide information on entrepreneurs' choice of study at the tertiary level. Therefore, further measures of education that capture skills learned in different fields should be developed. Moreover, the lack of historical data on entrepreneurship remains a shortcoming in the literature. A longer-term perspective would provide a better understanding of the progress that has been made toward gender equality in different aspects and drivers of entrepreneurial activity.

Open Access This article is distributed under the terms of the Creative Commons Attribution 4.0 International License (http:// creativecommons.org/licenses/by/4.0/), which permits unrestricted use, distribution, and reproduction in any medium, provided you give appropriate credit to the original author(s) and the source, provide a link to the Creative Commons license, and indicate if changes were made.

\section{References}

Acs, Z. J., Autio, E., \& Szerb, L. (2014). National systems of entrepreneurship: measurement issues and policy implications. Research Policy, 43(3), 476-494. https://doi. org/10.1016/j.respol.2013.08.016.

Alesina, A., Giuliano, P., \& Nunn, N. (2011). Fertility and the Plough. American Economic Review, 101(3), 499-503. https://doi.org/10.1257/aer.101.3.499.

Barro, R. J., \& Lee, J. W. (2013). A new data set of educational attainment in the world, 1950-2010. Journal of Development Economics, 104, 184-198. https://doi.org/10.1016/j. jdeveco.2012.10.001.

Bates, T. (1995). Self-employment entry across industry groups. Journal of Business Venturing, 10(2), 143-156. https://doi. org/10.1016/0883-9026(94)00018-P.

Baughn, C. C., Chua, B. L., \& Neupert, K. E. (2006). The normative context for women's participation in entrepreneruship: a multicountry study. Entrepreneurship Theory and Practice, 30(5), 687-708.

Baumol, W. J., \& Blinder, A. S. (2011). Microeconomics: principles and policy. Boston: Cengage Learning.

Blume-Kohout, M. (2014). Understanding the gender gap in STEM fields entrepreneurship. In SSRN scholarly paper. Rochester: Social Science Research Network https://papers. ssrn.com/abstract=2506835.

Bosma, N., van Praag, M., Thurik, R., \& de Wit., G. (2002). The value of human and social capital investments for the business performance of startups. Small Business Economics, 23(3), 227-236. https://doi.org/10.1023 /B:SBEJ.0000032032.21192.72.

Brush, C. G., \& Brush, C. G. (2006). Growth-oriented women entrepreneurs and their businesses: a global research perspective. Edward Elgar

Brush, C., Nancy, G., Carter, M., Gatewood, E., Greene, P., \& Hart, M. (2004). Clearing the hurdles: women building highgrowth businesses. Upper Saddle River: FT.

Bruton, G. D., Ahlstrom, D., \& Li, H.-L. (2010). Institutional Theory and Entrepreneurship: Where Are We Now and Where Do We Need to Move in the Future? Entrepreneurship Theory and Practice, 34(3), 421-440. https://doi.org/10.1111/j.1540-6520.2010.00390.x. 
Caliendo, M., Fossen, F., Kritikos, A., \& Wetter, M. (2015). The gender gap in entrepreneurship: not just a matter of personality. CESifo Economic Studies, 61(1), 202-238. https://doi. org/10.1093/cesifo/ifu023.

Caprile, M., Addis, E., Castaño, C., Klinge, I., Larios, M., Meulders, D., Sagebiel, F., Schiebinger, L., Valles, N., Vazquez-Cupeiro, S., Larios, M., Meulders, D., Muller, J., O’Dorchai, S., Palasik, M., Plasman, R., \& Roivas, S. (2012). Meta-analysis of gender and science research. Luxembourg: Office for Official Publications of the European Communities Available at: https://ec.europa. eu/research/science-society/document_library/pdf_06/metaanalysis-of-gender-and-science-research-synthesis-report. pdf.

De Bruin, A., Brush, C. G., \& Welter, F. (2006). Introduction to the special issue: towards building cumulative knowledge on women's entrepreneurship. Entrepreneurship Theory and Practice, 30(5), 585-593.

De Clercq, D., Hessels, J., \& van Stel, A. (2008). Knowledge spillovers and new ventures' export orientation. Small Business Economics, 31(3), 283-303. https://doi. org/10.1007/s11187-008-9132-Z.

Delmar, F., \& Davidsson, P. (2000). Where do they come from? Prevalence and characteristics of nascent entrepreneurs. Entrepreneurship \& Regional Development, 12(1), 1-23. https://doi.org/10.1080/089856200283063.

Dilli, S., Rijpma, A., \& Carmichael, S. (2015). Achieving gender equality: development versus historical legacies. CESifo Economic Studies, 61(1), 301-334. https://doi.org/10.1093 /cesifo/ifu027.

Dilli, S., Elert, N., \& Herrmann, A. (2018). Varieties of entrepreneurship: exploring the institutional foundations of different types through 'varieties of capitalism' arguments. Small Business Economics. https://doi.org/10.1007/s11187-0180002-z

Duquet, N., Glorieux, I., Laurijssen, I., \& Van Dorsselaer, Y. (2010). An unfinished job? The effect of subject choice and family formation processes on labour market outcomes of young men and women. Journal of Education and Work, 23(4), 319-338. https://doi.org/10.1080 $/ 13639080.2010 .484800$.

Eccles (2014) Genered socialization of STEM interests in the family. International Journal of Gender, Science and Technology, 7(2):117-132.

Elam, A., \& Terjesen, S. (2010). Gendered institutions and crossnational patterns of business creation for men and women. The European Journal of Development Research, 22(3), 331-348. https://doi.org/10.1057/ejdr.2010.19.

Estévez-Abe, M. (2006). Gendering the varieties of capitalism. A study of occupational segregation by sex in advanced industrial societies. World Politics, 59(1), 142-175. https://doi. org/10.1353/wp.2007.0016.

Estévez-Abe, M. (2009). Gender, Inequality, and Capitalism: The 'Varieties of Capitalism' and Women. Social Politics: International Studies in Gender, State \& Society, 16(2), 182-191. https://doi.org/10.1093/sp/jxp010.

Estrin, S., Korosteleva, J., \& Mickiewicz, T. (2013). Which institutions encourage entrepreneurial growth aspirations? Journal of Business Venturing, 28(4), 564-580. https://doi. org/10.1016/j.jbusvent.2012.05.001.
Estrin, S., \& Mickiewicz, T. (2011). Institutions and female entrepreneurship. Small Business Economics, 37(4), 397-415. https://doi.org/10.1007/s11187-011-9373-0.

Estrin, S., Mickiewicz, T., \& Stephan, U. (2016). Human capital in social and commercial entrepreneurship. Journal of Business Venturing, 31(4), 449-467. https://doi.org/10.1016/j. jbusvent.2016.05.003.

European Commission (2013). Encouraging female entrepreneurship_European Commission. Accessed May 30, 2017. http://ec.europa.eu/justice/gender-equality/otherinstitutions/good-practices/reviewseminars/seminars_2014 /female_entrepreneurship_en.htm.

Eurostat (2007). The rntrepreneurial gap between men and women. Issue Number 30/2007 - Product - Eurostat. Accessed March 16, 2017. http://ec.europa.eu/eurostat/en/web/products-statistics-infocus/-/KS-SF-07-030.

Flabbi, L., \& Tejada, M. (2012). "Gender Gaps in Education and Labor Market Outcomes in the United States: The Impact of Employers' Prejudice." SSRN Scholarly Paper. Rochester, NY: Social Science Research Network, December 1, 2012. https://papers.ssrn.com/abstract=2234315.

Folbre, N. (2009). Varieties of Patriarchal Capitalism. Social Politics: International Studies in Gender, State \& Society, 16(2), 204-209. https://doi.org/10.1093/sp/jxp011.

Greene, P. (2000). Self-employment as an economic behavior: an analysis of self-employed women's human and social capital. National Journal of Sociology, 12(1), 1-55.

Hall, P. A., \& Soskice, D. (2001). Varieties of capitalism: the institutional foundations of comparative advantage. Oxford: Oxford University Press.

Hechavarria, D. M., \& Reynolds, P. D. (2009). Cultural Norms \& Business Start-Ups: The Impact of National Values on Opportunity and Necessity Entrepreneurs. International Entrepreneurship and Management Journal, 5(4), 417-437. https://doi.org/10.1007/s11365-009-0115-6.

Henrekson, M., \& Sanandaji, T. (2014). Small business activity does not measure entrepreneurship. Proceedings of the National Academy of Sciences, 111(5), 1760-1765. https://doi.org/10.1073/pnas.1307204111.

Hox, J. (2010). Multilevel analysis (2nd ed.). London: Routledge.

Hughes, K. D., Jennings, J., Brush, C., Carter, S., \& Welter, F. (2012). Extending women's entrepreneurship research in new directions. Entrepreneurship Theory and Practice, 36(3), 429-442.

International Labour Office (ILO) (2017). LABORSTA. http://laborsta.ilo.org/default.html.

Jackson, G., \& Deeg, R. (2006) How many varieties of capitalism? Comparing the comparative institutional analyses of capitalist diversity. MPIfG Discussion Paper. Max Planck Institute for the Study of Societies, https://ideas.repec. org/p/zbw/mpifgd/062.html.

Jianakoplos, N. A., \& Bernasek, A. (1998). Are women more risk averse? Economic Inquiry, 36(4), 620-630.

Jones, S. (2008). Contextualising Entrepreneurship Education in HE: History, Policy and Gender. Belfast: Institute for Small Business \& Entrepreneurship Accessed 12 Feb 2018. https://www.academia.edu/181438/Contextualising Entrepreneurship_Education_in_HE_History_policy_and_ gender.

Kane, J. M., \& Mertz, J. E. (2011). Debunking myths about gender and mathematics performance. Notices of the American 
Mathematical Society, 59(1), 10-21. https://doi.org/10.1090 /noti790.

Kelly, D., Brush, C., Greene, P., Herrington, M., Ali, A., \& Pew, K. (2015). Women's Entrepreneurship. Wellesley, MA: Babson College. https://www.babson.edu/Academics/centers/blankcenter/globalresearch/gem/Documents/GEM\%202015\%20 Womens\%20Report.pdf.

Knight, F. H. (1982). Freedom and economic reforms: essays in economic and social philosophy. Indianapolis: Harper \& Row Liberty.

Langowitz, N., \& Minniti, M. (2007). The entrepreneurial propensity of women. Entrepreneurship Theory and Practice, 31(3), 341-365.

Leaper (2014) Do i belong?: gender, peer groups, and STEM achievement. International Journal of Gender, Science and Technology, 7(2):167-178.

Lewellyn, K. B., \& Muller-Kahle, M. I. (2016). A configurational approach to understanding gender differences in entrepreneurial activity: a fuzzy set analysis of 40 countries. International Entrepreneurship and Management Journal, 12(3), 765-790. https://doi.org/10.1007/s11365-015-0366-3.

Long, J. S. (1996). Regression models for categorical and limited dependent variables. Thousand Oaks: SAGE Publications, Inc..

Maas, C. J., \& Hox, J. J. (2005). Sufficient Sample Sizes for Multilevel Modeling. Methodology, 1(3), 86-92.

Mandel, H., \& Shalev, M. (2009). Gender, Class, and Varieties of Capitalism. Social Politics: International Studies in Gender, State \& Society, 16(2), 161-181. https://doi.org/10.1093 /sp/jxp006.

Marques, H. (2017). The routineness of tasks, gender and culture in entrepreneurship. Socio-Economic Review, 15(4), 815851. https://doi.org/10.1093/ser/mwx017.

McCracken, K., Marquez, S., Kwong, C., Stephan, U., Castagnoli, A., \& Dlouhá, M. (2015). Women's entrepreneurship: closing the gender gap in access to financial and other services and in social entrepreneurship. Accessed May 20, 2017. https://research.aston.ac.uk/portal/en/researchoutput/womensentrepreneurship-closing-the-gender-gap-in-access-tofinancial-and-other-services-and-in-social-entrepreneurship (56 acd6c8-9d6a-4182-9b73-7efeea23d4d6)/export.html.

Millán, J. M., Congregado, E., Román, C., van Praag, M., \& van Stel, A. (2014). The value of an educated population for an individual's entrepreneurship success. Journal of Business Venturing, 29(5), 612-632. https://doi.org/10.1016/j. jbusvent.2013.09.003.

Minniti, M. (2009). Gender issues in entrepreneurship. Foundations and Trends in Entrepreneurship, 5(7-8), 497621. https://doi.org/10.1561/0300000021.

Minniti, M., \& Nardone, C. (2007). Being in someone else's shoes: the role of gender in nascent entrepreneurship. Small Business Economics, 28(2-3), 223-238. https://doi. org/10.1007/s11187-006-9017-y.

Minniti, M., \& Naudé, W. (2010). What do we know about the patterns and determinants of female entrepreneurship across countries? The European Journal of Development Research, 22(3), 277-293. https://doi.org/10.1057/ejdr.2010.17.

OECD. (2012). Gender equality in education. In OECD (Ed.), Closing the gender gap: act now. Paris: OECD.
OECD. (2015). Trends shaping education 2015 spotlight 7: gender equality. OECD http://www.oecd.org/edu/ceri/Spotlight7GenderEquality.pdf.

OECD. (2016a). The missing entrepreneurs 2015 (p. 2015). Paris: Organization for Economic Co-operation and Development http://www.oecd-ilibrary.org/content/book/9789264226418en.

OECD (2016b). Gross domestic spending on R\&D (indicator). Paris: OECD. https://data.oecd.org/rd/gross-domesticspending-on-r-d.htm.

Perrons, D. (1995). Economic strategies, welfare regimes and gender inequality in employment in the European Union. European Urban and Regional Studies, 2(2), 99-120. https://doi.org/10.1177/096977649500200202.

Ramos-Rodriguez, A., Medina-Garrido, J., \& Ruiz-Navarro, J. (2012). Determinants of hotels and restaurants entrepreneurship: a study using GEM data. International Journal of Hospitality Management, 31(2), 579-587. https://doi. org/10.1016/j.ijhm.2011.08.003.

Reimer, D., \& Steinmetz, S. (2009). Highly educated but in the wrong field? European Societies, 11(5), 723-746. https://doi. org/10.1080/14616690802326400.

Reynolds, P. D., Bosma, N., Autio, E., Hunt, S., De Bono, N., Servais, I., Lopez-Garcia, P., \& Chin, N. (2005). Global entrepreneurship monitor: data collection design and implementation 1998-2003. Small Business Economics, 24(3), 205-231. https://doi.org/10.1007/s11187-005-1980-1.

Silva, O. (2007). The jack-of-all-trades entrepreneur: innate talent or acquired skill? Economics Letters, 97(2), 118-123. https://doi.org/10.1016/j.econlet.2007.02.027.

Simón-Moya, V., Revuelto-Taboada, L., \& Fernández Guerrero, R. (2014). Institutional and Economic Drivers of Entrepreneurship: An International Perspective. Journal of Business Research, 67(5), 715-721. https://doi.org/10.1016 j.j.jbusres.2013.11.033.

Stefani, M., \& Vacca, V. (2015). Small firms' credit access in the Euro area: does gender matter? CESifo Economic Studies, 61(1), 165-201. https://doi.org/10.1093/cesifo/ifu031.

Stenholm, P., Acs, Z. J., \& Wuebker, R. (2013). Exploring Country-Level Institutional Arrangements on the Rate and Type of Entrepreneurial Activity. Journal of Business Venturing, Special Issue: Institutions, Entrepreneurs, Community, 28(1), 176-193. https://doi.org/10.1016/j. jbusvent.2011.11.002.

UNESCO. (2015). The Statistical Yearbooks. Paris: UNESCO.

Van Der Sluis, J., Van Praag, M., \& Vijverberg, W. (2008). Education and entrepreneurship selection and performance: a review of the empirical literature. Journal of Economic Surveys, 22(5), 795-841.

Van Der Zwan, P., Verheul, I., \& Thurik, A. R. (2011). The entrepreneurial ladder, gender, and regional development. Small Business Economics, 39(3), 627-643. https://doi. org/10.1007/s11187-011-9334-7.

Van Der Zwan, P., Verheul, I., Thurik, A. R., \& Grilo, I. (2013). Entrepreneurial progress: climbing the entrepreneurial ladder in Europe and the United States. Regional Studies, 47(5), 803-825. https://doi.org/10.1080/00343404.2011.598504.

Verheul, I., \& Thurik, R. (2001). Start-up capital: does gender matter? Small Business Economics, 16(4), 329-345. https://doi.org/10.1023/A:1011178629240. 
Verheul, I., Van Stel, A., \& Thurik, R. (2006). Explaining female and male entrepreneurship at the country level. Entrepreneurship \& Regional Development, 18(2), 151183. https://doi.org/10.1080/08985620500532053.

Wennekers, S., \& Thurik, R. (1999). Linking entrepreneurship and economic growth. Small Business Economics, 13(1), 27-56. https://doi.org/10.1023/A:1008063200484.
World Bank (2016). GDP per capita. http://data.worldbank. org/indicator.

World Bank. (2011). World Development Report 2012: Gender Equality and Development. Washington, DC: World Bank Publications. 